\title{
MONAZITE-(Sm), A NEW MEMBER OF THE MONAZITE GROUP FROM THE ANNIE CLAIM \#3 GRANITIC PEGMATITE, SOUTHEASTERN MANITOBA
}

\author{
Morgan MASAU $§$, Petr ČERNÝ, Mark A. COOPER ANd Ron CHAPMAN \\ Department of Geological Sciences, University of Manitoba, Winnipeg, Manitoba R3T 2N2, Canada \\ JoEL D. GRICE \\ Research Division, Canadian Museum of Nature, Ottawa, Ontario K1P 6P4, Canada
}

\begin{abstract}
Monazite-(Sm) was found in the Annie Claim \#3 pod of lepidolite-subtype granitic pegmatite within the Greer Lake intrusion of pegmatitic leucogranite, in the Archean Bird River Subprovince of the Superior Province, in southeastern Manitoba. It occurs as tabular crystals $\leq 0.4 \mathrm{~mm}$ in diameter, associated with manganocolumbite, quartz, albite and lithian muscovite. Monazite-(Sm) is yellowish, translucent, with a white streak, vitreous to greasy luster, and no observed fluorescence. One good cleavage is present, tenacity is brittle, and the fracture is uneven. Monazite-(Sm) has no observable pleochroism; $\alpha$ 1.768 (5), $\beta$ 1.771(3), $\gamma$ $>1.808(3) ; 2 V_{\text {meas }} 29(8)^{\circ}, X=b, Z \wedge c=9^{\circ}$ ( $\beta$ obtuse). It is monoclinic, space group $P 2_{1} / n$; a refinement from single-crystal and powder (Gandolfi) X-ray-diffraction data gave $a$ 6.725(1), 6.739(3), b 6.936(1), 6.951(3), $c$ 6.448(1), 6.462(3) $\AA, \beta 104.02(1)^{\circ}$, 104.03(4) $)^{\circ}, V$ 291.8(1), 293.6(2) $\AA^{3}, Z=4$; $\mathrm{D}_{\text {calc }}$ derived from average chemical composition is 5.512 and $5.478 \mathrm{~g} / \mathrm{cm}^{3}$. The strongest six lines of the (Gandolfi) X-ray-diffraction pattern $[d$ in $\AA(I)(h k l)]$ are: $4.647(5)(011), 4.164(8)(\overline{1} 11), 3.492(4)(111,020)$, $3.264(7)(200), 3.065(10)(120)$, and 2.857(9)(112,012). The monazite-(Sm) contains, in wt.\%, up to $14.29 \mathrm{Sm}_{2} \mathrm{O}_{3}, 13.48 \mathrm{Gd}_{2} \mathrm{O}_{3}$ and $6.28 \mathrm{Nd}_{2} \mathrm{O}_{3}$, and moderate percentages of the huttonite and brabantite components. The most Sm-rich composition gives $\left(\mathrm{Sm}_{0.197} \mathrm{Gd}_{0.179} \mathrm{Ce}_{0.148} \mathrm{Th}_{0.125} \mathrm{Ca}_{0.107} \mathrm{Nd}_{0.090} \mathrm{La}_{0.030} \mathrm{Y}_{0.030} \mathrm{Pr}_{0.023} \mathrm{~Tb}_{0.017} \mathrm{Zr}_{0.017} \mathrm{Dy}_{0.016} \mathrm{~Pb}_{0.016} \mathrm{U}_{0.002}\right)_{\Sigma 0.997}\left(\mathrm{P}_{0.963} \mathrm{Si}_{0.044}\right)_{\Sigma 1.007} \mathrm{O}_{4}$. Adjustment of $\mathrm{U}$ and $\mathrm{Th}$ of the monazite-(Sm) to their original contents $2.64 \mathrm{Ga}$ ago slightly improves the stoichiometry and proves that all the $\mathrm{Pb}$ present is radiogenic. The middle- $R E E$-dominant signature of the Annie Claim \#3 monazite-( $\mathrm{Sm})$ is shared with the broadly associated $\mathrm{Y}(\mathrm{Ta}, \mathrm{Nb}) \mathrm{O}_{4}$ mineral (formanite?) and dysprosian xenotime-(Y); this exotic pattern of $R E E$ abundances is possibly generated by selective and differential complexing of $R E E$ in the granite-to-pegmatite sequence of solidification.
\end{abstract}

Keywords: monazite-(Sm), new mineral species, rare-earth elements, granitic pegmatite, Annie Claim \#3, Manitoba, Canada.

\section{SOMMAIRE}

Nous avons découvert la monazite-(Sm) dans la lentille de pegmatite granitique à lépidolite dite Annie Claim \#3, au sein du massif intrusif du lac Greer, dans la sous-province de Bird River de la Province du Supérieur, dans l'Archéen du sud-est du Manitoba. Elle se présente en cristaux tabulaires atteignant $0.4 \mathrm{~mm}$ en diamètre, associée à manganocolumbite, quartz, albite et muscovite lithinifère. Les cristaux de monazite-( $\mathrm{Sm})$ sont jaunâtres, translucides, ayant une rayure blanche, un éclat vitreux à résineux, sans fluorescence. Nous décelons un bon clivage; la tenacité est cassante, et la fracture, inégale. La monazite-(Sm) ne montre aucun pléochroïsme observable; $\alpha 1.768$ (5), $\beta$ 1.771(3), $\gamma>1.808(3) ; 2 V_{\text {meas }} 29(8)^{\circ}, X=b, Z \wedge c=9^{\circ}$ (dans l'angle $\beta$ obtus). Elle est monoclinique, groupe spatial $P 2_{1} / n$; un affinement des paramètres réticulaires à partir des données prélevées sur monocristal et sur poudre (méthode de Gandolfi) a donné $a$ 6.725(1), 6.739(3), $b$ 6.936(1), 6.951(3), $c 6.448(1), 6.462(3) \AA$ $104.02(1)^{\circ}, 104.03(4)^{\circ}, V 291.8(1), 293.6(2) \AA^{3}, Z=4$. La densité calculée à partir de la composition moyenne est 5.512 et 5.478 $\mathrm{g} / \mathrm{cm}^{3}$. Les six raies les plus intenses du spectre de diffraction X (Gandolfi) $[d$ en $\AA(I)(h k l)]$ sont: 4.647(5)(011), 4.164(8)(111), 3.492(4)(111,020), 3.264(7)(200), 3.065(10)(120), et 2.857(9)(112,012). La monazite-(Sm) contient jusqu'à $14.29 \% \mathrm{Sm}_{2} \mathrm{O}_{3}$, $13.48 \% \mathrm{Gd}_{2} \mathrm{O}_{3}$ et $6.28 \% \mathrm{Nd}_{2} \mathrm{O}_{3}$ (poids), et des proportions appréciables des composantes huttonite et brabantite. La composition la plus enrichie en $\mathrm{Sm}$ donne $\left(\mathrm{Sm}_{0.197} \mathrm{Gd}_{0.179} \mathrm{Ce}_{0.148} \mathrm{Th}_{0.125} \mathrm{Ca}_{0.107} \mathrm{Nd}_{0.090} \mathrm{La}_{0.030} \mathrm{Y}_{0.030} \mathrm{Pr}_{0.023} \mathrm{~Tb}_{0.017} \mathrm{Zr}_{0.017} \mathrm{Dy}_{0.016} \mathrm{~Pb}_{0.016} \mathrm{U}_{0.002}\right)_{\Sigma 0.997}$ $\left(\mathrm{P}_{0.963} \mathrm{Si}_{0.044}\right)_{\Sigma 1.007} \mathrm{O}_{4}$. Un ajustement des teneurs en $\mathrm{U}$ et $\mathrm{Th}$ de la monazite-(Sm) à leurs teneurs originelles il y a $2.64 \mathrm{Ga}$ améliore légèrement la stoechiométrie et prouve que tout le $\mathrm{Pb}$ est radiogénique. L'enrichissement de ce minéral en terres rares moyennes se voit aussi dans un minéral associé de composition $\mathrm{Y}(\mathrm{Ta}, \mathrm{Nb}) \mathrm{O}_{4}$ (formanite?) et le xénotime-(Y) enrichi en dysprosium

$\S \quad$ Present address: Department of Geology and Geophysics, University of New Orleans, New Orleans, Louisiana 70148, U.S.A. E-mail address: morgan_masau@hotmail.com 
à Annie Claim \#3. Cet enrichissement inhabituel pourrait bien refléter la complexation sélective et différentielle des terres rares au cours de la solidification progressive sur l'intervalle granite-pegmatite.

(Traduit par la Rédaction)

Mots-clés: monazite-(Sm), nouvelle espèce minérale, terres rares, pegmatite granitique, Annie Claim \#3, Manitoba, Canada.

\section{INTRODUCTION}

There are three known members of the monazite group sensu stricto. They contain as dominant trivalent cations the three lightest, largest and geochemically most abundant rare-earth (REE) elements, $\mathrm{La}, \mathrm{Ce}$ and $\mathrm{Nd}$, in accord with their preference for the monazite structure (Ni et al. 1995). Monazite-(Ce) is by far the most widespread member, whereas monazite-(La) is rarely observed, and monazite-(Nd) seems to be known so far from only three localities (Gaines et al. 1997, Anthony et al. 2000).

Here we report on a new monazite-group mineral, the REE composition of which is distinctly shifted toward the middle REE (MREE): monazite-(Sm) in fact has $\mathrm{Gd}$ a close second in importance to $\mathrm{Sm}$. Moreover, $\mathrm{Tb}$ is the third most abundant REE in terms of chondrite-normalized values. The new mineral is named in accordance with recommendations of the Commission on New Minerals and Mineral Names of the International Mineralogical Association for REE minerals. The species and the name were approved by the above Commission (IMA 2000-001). The polished section analyzed by electron microprobe (EMPA), the single crystal used for X-ray diffraction (XRD) and optical study, and the three microchips used for Gandolfi XRD are catalogued under \#M7181 in the R.B. Ferguson Museum of Mineralogy, Department of Geological Sciences, University of Manitoba.

\section{The Parent Pegmatite}

Monazite-(Sm) was found in the Annie Claim \#3 granitic pegmatite, a zoned body of the lepidolite subtype located in the southwestern margin of its parent Greer Lake pegmatitic granite. This LCT-family granite and derived pegmatites, dated at $2640 \pm 7 \mathrm{Ma}$ (Baadsgaard \& Cerný 1993), were intruded in metabasalts of the Lamprey Falls Formation of the Bird River Greenstone Belt, in the Bird River Subprovince of the western part of the Superior Province of the Canadian Shield; the geographic location is $1.2 \mathrm{~km}$ northwest of Greer Lake in southeastern Manitoba, close to Winnipeg River, at latitude $50^{\circ} 21^{\prime} 12^{\prime \prime} \mathrm{N}$ and longitude $95^{\circ} 20^{\prime}$ 18 "W. Černý et al. (1981) provided details concerning the regional geology.

The subellipsoidal, subhorizontal body of the pegmatite is approximately $7 \times 10$ meters in size, with distinct concentric zoning (Masau 1999). The zones show an inward progression, changing in texture and mineral assemblage, exemplified by a border-to-core succession of five main types of mica (from muscovite to lithian muscovite to lepidolite), associated mainly with albite and quartz. Microcline perthite is sporadic in the outermost zones and absent from the intermediate and inner zones. Accessory minerals include spessartine, cesian beryl, cassiterite with exsolved zirconian-hafnian wodginite (Masau et al. 2000a), manganocolumbite, manganotantalite and rare primary wodginite, microlite, uranpyrochlore, ferrotapiolite, probable formanite-(Y), fluorapatite, zircon, coffinite, uraninite, dysprosian xenotime-(Y) (Masau et al. 2000b) and monazite-(Sm). The pegmatite and the parent pegmatitic granite do not contain any minerals of $\mathrm{B}$ or phosphates of $\mathrm{Li}, \mathrm{Al}, \mathrm{Fe}$ or $\mathrm{Mn}$, and sulfides are extremely rare.

\section{EXPERIMENTAL}

Monazite-(Sm) was analyzed using a Cameca SX50 electron microprobe in wavelength-dispersion mode, under the following conditions: operating voltage 20 $\mathrm{kV}$, beam current $40 \mathrm{nA}$, beam size $3 \mu \mathrm{m}$. Counting times for peak and background determinations were 20 $\mathrm{s}$ and $10 \mathrm{~s}$, respectively, for $\mathrm{Si}, \mathrm{P}, \mathrm{Ca}, \mathrm{Zr}, \mathrm{Dy}, \mathrm{Pb}, \mathrm{Th}$ and $\mathrm{U}$; for the remaining elements, the values were 40 and $20 \mathrm{~s}$, respectively. Monazite-( $\mathrm{Sm})$ was analyzed using the following standards: $\mathrm{SmPO}_{4}(\mathrm{P} K \alpha, \mathrm{Sm} L \beta)$ and other individual synthetic phosphates $A \mathrm{PO}_{4}$ ( $L \alpha$ for $\mathrm{Y}$, $\mathrm{La}, \mathrm{Ce}, \mathrm{Nd}$ and $\mathrm{Tb}, L \beta$ for $\mathrm{Pr}, \mathrm{Gd}$ and $\mathrm{Dy})$, zircon $(\mathrm{Si} K \alpha$, $\mathrm{Zr} L \beta)$, mimetite $(\mathrm{Pb} M \beta), \mathrm{ThO}_{2}(\mathrm{Th} M \alpha), \mathrm{UO}_{2}(\mathrm{U} M \beta)$ and Wilberforce apatite $(\mathrm{CaK} \alpha)$. Concentrations of Ho, $\mathrm{Er}$ and $\mathrm{Tm}$ [the last adjusted for overlap with Sm using the method of Åmli \& Griffin (1975) and Nagy (1993)] were found to be below detection limits $(0.03,0.02$ and 0.04 wt. $\%$, respectively, at $100 \mathrm{nA}$ and $100 \mathrm{~s}$ ). Contents of $\mathrm{Yb}$ and $\mathrm{Lu}$ were at about their respective limits of detection under these conditions (0.02 and 0.05 wt.\%); $\mathrm{Na}, \mathrm{K}, \mathrm{Mn}, \mathrm{Fe}, \mathrm{Mn}, \mathrm{Ba}, \mathrm{Sr}, \mathrm{As}, \mathrm{S}, \mathrm{F}, \mathrm{Nb}$ and Ta were not detected. The analytical data were reduced and corrected by the PAP method of Pouchou \& Pichoir (1984, 1985). Chondritic REE values of Taylor \& McLennan (1985) were used to normalize the REE contents.

Single-crystal data were collected on a Bruker automated four-circle diffractometer equipped with a CCD detector, using $\mathrm{Mo} K \alpha$ radiation with $\lambda=0.71073 \AA$. Unit-cell dimensions were refined from 106 diffraction maxima ( $\mathrm{I} / \mathrm{sig}>10$ ) with $2 \theta$ up to $60^{\circ}$. Powder data were recorded with a $114.6 \mathrm{~mm}$ Debye-Scherrer camera with Gandolfi attachment, using Ni-filtered $\mathrm{Cu} K \alpha$ radiation with $\lambda=1.5418 \AA$. 


\section{MonAZITE-(SM)}

Monazite-(Sm) was found to be closely aggregated with platy crystals of manganocolumbite in the inner intermediate zone of the parent pegmatite. The aggregate is associated with quartz, "cleavelandite" and curvilamellar lithian muscovite. No other REE minerals are present in close proximity to monazite-(Sm), although some do occur elsewhere in the pegmatite, as mentioned above.

Platy subhedral crystals of monazite-(Sm) attain a maximum dimension of $0.4 \mathrm{~mm}$ (Fig. 1). They are brittle, yellowish and translucent to transparent, with vitreous to slightly greasy luster and white streak. Microscopic fragments show one good cleavage and, otherwise, uneven fracture-surfaces. No fluorescence was observed in UV light. Density and hardness could not be measured. However, density calculated from the average chemical composition is 5.512 and $5.478 \mathrm{~g} / \mathrm{cm}^{3}$ for unit-cell dimensions derived from X-ray diffraction single-crystal and powder (Gandolfi) data, respectively. Optical properties measured at a wavelength of 589.9 $\mathrm{nm}$ are $\alpha 1.768(5), \beta 1.771(3), \gamma>1.808$ (3) [no immersion liquid with $\mathrm{n}>1.808$ was available to the authors; $\gamma$ calculated from $\alpha, \beta$ and $2 V$ (measured) is 1.818]. The measured $(+) 2 V$ is $29(8)^{\circ}$; the value calculated using 1.808 as a minimum for $\gamma$ is $32^{\circ} ; X=b, Z \wedge c=9^{\circ}(\beta$ obtuse). Microscopic fragments of monazite-( $\mathrm{Sm})$ are colorless.

The chemical composition of monazite-( $\mathrm{Sm})$ is shown in Table 1 . The average composition of the fragments used for XRD and optical study (Table 1, \#1) yields a formula with Sm distinctly dominant over Gd, $\mathrm{Ce}$, Th and $\mathrm{Ca}$, with subordinate to minor contents of other REE. The dominance of Sm and Gd over other cations is even better expressed in the most $\mathrm{Sm}$-enriched composition (Table 1, \#2): $\left(\mathrm{Sm}_{0.197} \mathrm{Gd}_{0.179} \mathrm{Ce}_{0.148}\right.$ $\mathrm{Th}_{0.125} \mathrm{Ca}_{0.107} \mathrm{Nd}_{0.090} \mathrm{La}_{0.030} \mathrm{Y}_{0.030} \mathrm{Pr}_{0.023} \mathrm{~Tb}_{0.017} \mathrm{Zr}_{0.017}$ $\left.\mathrm{Dy}_{0.016} \mathrm{~Pb}_{0.016} \mathrm{U}_{0.002}\right)_{\Sigma 0.997}\left(\mathrm{P}_{0.963} \mathrm{Si}_{0.044}\right)_{\Sigma 1.007} \mathrm{O}_{4}$. However, note that this extreme composition was not obtained on any of the grains extracted from the polished section for XRD work and determination of physical properties.

Slight improvement of stoichiometry and charge balance is achieved by calculation of the original $U$ and Th contents of the monazite-(Sm) as they were at the time of crystallization $2.64 \mathrm{Ga}$ ago (Table $1, \# 1^{*}$ and $2 *)$. The virtually identical atomic content of presentday $\mathrm{Pb}(0.023$ and 0.016 in \#1 and 2) with those of decayed $\mathrm{U}+\mathrm{Th}(0.023$ and $0.018 ; 1 *$ less 1 and $2 *$ less 2 ,

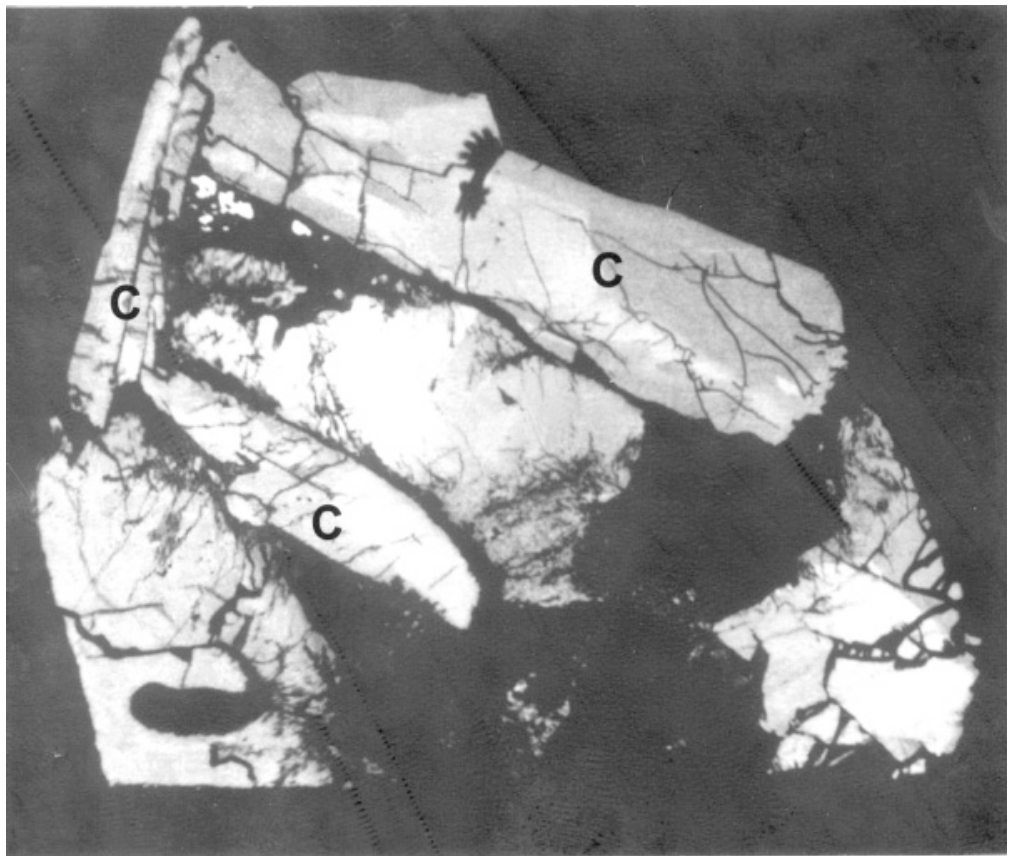

FIG. 1. Back-scattered electron image of the main aggregate of monazite-(Sm) and manganocolumbite $(\mathrm{C})$ embedded in quartz (black). Variations in brightness of the monazite-(Sm) are controlled by the Th content, whereas the ratio $\mathrm{Nb} / \mathrm{Ta}$ affects manganotantalite. The aggregate is $0.8 \mathrm{~mm}$ across. 
respectively) shows that all $\mathrm{Pb}$ is radiogenic, and that any potential loss of $\mathrm{Pb}$ from the monazite structure has been negligible.

The current content of Th is substantial, but it gives only 4 to 10 mole $\%$ of the huttonite component $\mathrm{ThSiO}_{4}$ and 10 to 14 mole \% of the brabantite component $\mathrm{CaTh}\left(\mathrm{PO}_{4}\right)_{2}$, when split between the available $\mathrm{Si}$ and $\mathrm{Ca}$, respectively. The stoichiometry of the brabantite and
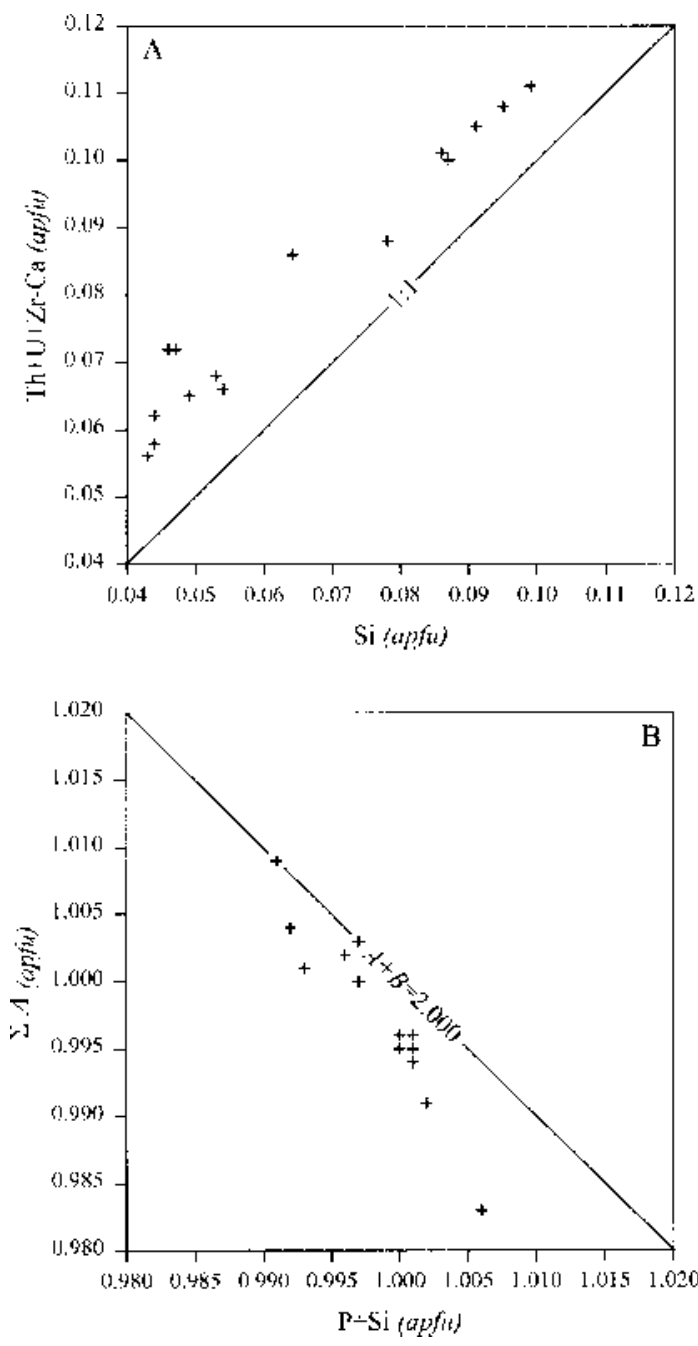

FIG. 2. (A) $\mathrm{Th}+\mathrm{Zr}+\mathrm{U}-\mathrm{Ca}$ versus $\mathrm{Si}$ (atoms per formula units) in monazite-(Sm) adjusted for $2.64 \mathrm{Ga}$ of $\mathrm{U}$ and $\mathrm{Th}$ decay; close adherence to the 1:1 ratio confirms solid solution toward the huttonite and brabantite components. (B) Sum of $A$ cations versus $\mathrm{P}+\mathrm{Si}$ (atoms per formula unit normalized to four atoms of oxygen) in monazite-(Sm); except for a single point, all data correspond to the ideal 1:1 ratio within experimental error. huttonite components in solid solution is confirmed by the good alignment of atomic Si versus $(\mathrm{Th}+\mathrm{Zr}+\mathrm{U}-$ $\mathrm{Ca}$ ) in Figure 2A, although slightly shifted in favor of the latter elements. Good analytical totals and stoichiometry calculated on an anhydrous basis indicate that any potential role of a tetrahedral array of $(\mathrm{OH})$ groups must be negligible, if any, in both the current and original compositions. Figure $2 \mathrm{~B}$ shows that the $A:(\mathrm{P}+\mathrm{Si})$ ratio equals 1 within the limits of analytical error.

Unit-cell dimensions were derived from single-crystal and powder data: $a$ 6.725(1), 6.739(3), $b$ 6.936(1), 6.951(3), c 6.448(1), 6.462(3) $\AA$, $\beta$ 104.02(1) ${ }^{\circ}$, 104.03(4) ${ }^{\circ}, V$ 291.8(1), 293.6(2) $\AA^{3}, Z=4$. The XRD powder data are shown in Table 2 . Systematically absent diffraction-maxima in the single-crystal and powder data are consistent with space group $P 2_{1} / n$. Both the unit-cell dimensions and the powder data closely match those available for other monazite-group minerals (e.g., Ni et al. 1995). However, the substantial contents of Th and $\mathrm{Ca}$ do not permit direct comparison with cell-parameter values calculated on the basis of occupancy by the REE alone (Ni et al. 1995).

\section{Geochemical Considerations}

As noted in the introduction, dominance of $\mathrm{La}$ or $\mathrm{Nd}$ is rather rare in monazite-group minerals, although both these elements are commonly the second and third most abundant REE in monazite-(Ce). The extent of enrichment in $\mathrm{Sm}$ (and $\mathrm{Gd}$ ) shown in Figure 3 for monazite$(\mathrm{Sm})$ has not so far been reported. The highest $\mathrm{Sm}_{2} \mathrm{O}_{3}$

TAELE ]. REPRESENTATIVE COMPOSITIONS OF MONAZITE-(Sm)

\begin{tabular}{|c|c|c|c|c|c|c|c|c|c|}
\hline & 1 & 2 & $I^{*}$ & $2^{*}$ & & 1 & 2 & $1^{*}$ & $2^{*}$ \\
\hline $\mathrm{O}_{\mathrm{s}}$ & 27.48 & 899 & 27.48 & 8.39 & $P$ & 942 & 0.963 & 0936 & 0,958 \\
\hline \multirow[t]{2}{*}{$\mathrm{siO}_{2}$} & 53 & .09 & 53 & 09 & $\mathrm{si}$ & & & & 0 \\
\hline & & & & & $E H$ & 004 & 1.007 & 0.508 & 1.6 \\
\hline $\mathrm{O}_{2}$ & 0.71 & 0.89 & 0.71 & 0.89 & $Z_{\tau}$ & 014 & 0.017 & 0.014 & 00 \\
\hline$O_{2}$ & 16.27 & 13.69 & 18.50 & 5.56 & Th & 150 & 0.125 & 0. 169 & 0.1 \\
\hline $\mathrm{O}_{2}$ & 062 & 0.28 & 0.99 & 1.44 & & 0005 & 0.002 & 0.009 & 00 \\
\hline${ }_{2} \mathrm{O}_{3}$ & 1.2 & 1.40 & 1.29 & 1.4 & & 28 & 0.000 & 0.028 & 0.0 \\
\hline$a_{1}$ & 10 & 202 & 10 & & & 12 & 0.030 & 0.031 & 00 \\
\hline $\mathrm{e}_{1} \mathrm{O}_{3}$ & 10.04 & 1007 & 10.04 & 10.07 & & 9 & 0.1 & 0. & 01 \\
\hline$f_{1}$ & & 60 & & & & & 0.023 & 0.0 & 00 \\
\hline $\mathrm{H}_{2} \mathrm{O}_{1}$ & 00 & 6.28 & 03 & 28 & & 87 & 190 & 0.087 & 0.089 \\
\hline $\mathrm{m}_{2} \mathrm{O}_{3}$ & 13.02 & 1429 & 13.02 & 29 & & 2 & 197 & $8 \mathrm{l}$ & 0.196 \\
\hline $\mathrm{t}_{2} \mathrm{O}_{\mathrm{k}}$ & 1206 & 1348 & 1206 & 13.48 & & & 9 & 0.161 & 0.1 \\
\hline $\mathrm{b}_{2} \mathrm{O}_{3}$ & 1.1 & 1.28 & & 1 & 1 & 015 & 0.017 & 0.015 & 0.017 \\
\hline & 1.i & 121 & & 12 & & a] 5 & 0.016 & 0015 & 0016 \\
\hline & 0 & & & & & & & & - \\
\hline L & 005 & 10 & & 0.0 & & & & & \\
\hline 10 & 2.75 & 2.49 & 1.75 & 2.4 & $c$ & 19 & 107 & 0.119 & 0.106 \\
\hline & 2.14 & 1.45 & - & - & $\mathrm{Pb}$ & 3 & 0.016 & - & - \\
\hline & & & & & & 1.00014 & .996 & 1.000 & 0.994 \\
\hline
\end{tabular}

Total $\quad 100.01 \quad 90.97 \quad 100.40100 .50 \quad 5 t+B) 2.008 \quad 2.003 \quad 1.9 \% \quad 1995$

I: wt.\% awerage of 3 grains used for collecting physical, optical and crystal

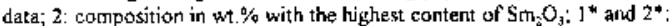
cesnositions 1 and 2 adjusted for 2.64 Ga of radieactive decay of $U$ and $T$ h; atomic contents normalized to 4 oxygen atoms. Sot detected: Na, $K_{1}, \mathrm{Mg}$. $\mathrm{Mrn}, \mathrm{Fe}, \mathrm{Ba}, \mathrm{Sr}, \mathrm{Sc}, \mathrm{Fu}, \mathrm{H}_{\mathrm{r}}, \mathrm{Er}, \mathrm{Tm}, \mathrm{As}, \mathrm{Nb}_{\mathrm{r}} \mathrm{Ta}, \mathrm{S}, \mathrm{F}$ 
content noted to date is $9.7 \mathrm{wt} . \%$ (accompanied by 4.3 wt. $\% \mathrm{Gd}_{2} \mathrm{O}_{3}$ ), associated with extreme $\mathrm{Nd}$ in monazite$(\mathrm{Nd})$ from its type locality, where it occurs as a hydrothermal mineral in Alpine veins; Graeser \& Schwander (1987), Demartin et al. (1991). High Sm and Gd also were reported in an incompletely analyzed sample from Chernaya Salma in Karelia (Vainshtein et al. 1956, quoted in Neumann et al. 1966). Otherwise, Sm invariably is subordinate to minor with respect to the major $R E E$, as is $\mathrm{Gd}$. This is abundantly documented in general reviews of monazite (e.g., Neumann et al. 1966, Fleischer \& Altschuler 1969), as well as in statistically extensive studies of monazite from a variety of specific petrological environments: granitic suites, granitic pegmatites, tin deposits, Alpine fissures, sediments and metamorphic rocks (e.g., Lee \& Bastron 1967, Donnot et al. 1973, Petruk \& Owens 1975, Burnotte et al. 1989, Wark \& Miller 1993, Watt 1995, Förster \& Rhede 1995, Franz et al. 1996, van Emden et al. 1997, Förster 1998).

What may be the reason for the unique enrichment of the Annie Claim \#3 monazite-(Sm) in Sm and Gd? Crystal-chemical factors would favor $\mathrm{Ce}>\mathrm{La}>\mathrm{Nd}$ over and above the MREE and HREE. Partitioning of these three elements into competing minerals cannot be invoked, as the associated minerals are not prominent $R E E$ carriers. The close similarity of ionic radii of $\mathrm{Th}, \mathrm{Sm}$ and Gd, invoked by Förster et al. (2000) to explain the enrichment of Sm and $\mathrm{Gd}$ in huttonite, cannot be responsible, as monazite is routinely enriched in Th, but its concentration is not correlated with the content of Sm or Gd.

A significant clue to the puzzle is the abundance of the $M R E E$ in the other REE minerals in the Annie Claim \#3 pegmatite: xenotime-(Y) is strongly enriched in Dy,

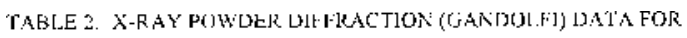
MOYATITr-(G):1)

\begin{tabular}{|c|c|c|c|c|c|c|c|}
\hline$t_{\mathrm{ex}}$ & $d_{1 \times x=\infty} \not$ & $a_{1}, \bar{A}$ & $n d$ & $r_{\mathrm{m} x}$ & 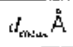 & $d_{\text {, J1, }} \AA$ & $\sqrt{i k}$ \\
\hline 40 & 5191 & 5.109 & (i) & $\therefore 10$ & 2.375 & $23 \mathrm{Ht}$ & 220 \\
\hline 50 & 4.647 & 4.655 & וֹ & $=10$ & 2.3 .30 & 2.379 & $\overline{1} 22$ \\
\hline 80 & 4. $16-1$ & 41.63 & ¿II & סיז & 2174 & 2.173 & $03 !$ \\
\hline .30 & 4.064 & 4060 & 101 & 30 & 2.146 & 2.147 & ] 63 \\
\hline \multirow[t]{2}{*}{ 4UE } & .1492 & 35 & I] & 20 & $\therefore 127$ & מבר 7 & $\overline{3} 11$ \\
\hline & .1 & 3475 & 090 & 20 & 2. 106 & 2.106 & 221 \\
\hline 70 & .3264 & 3269 & 200 & Sic & 1950 & 1.949) & 212 \\
\hline$<0$ & .136 & 31.39 & בטנ & $\therefore 10$ & 1920 & 1919 & $30 !$ \\
\hline 100 & .065 & 3000 & 120 & 10 & 1.385 & $1.38 \%$ & Ij \\
\hline 10 & 2952 & 2.458 & 214 & 30 & $1.86 \overline{7}$ & 1864 & $\overline{3} 32$ \\
\hline \multirow[t]{2}{*}{90} & 2.857 & 7800 & ד & 10 & $: 347$ & $1.8 \cdot 16$ & 320 \\
\hline & " & 2557 & (1) 12 & 10 & $: 900$ & 1.791 & 023 \\
\hline 10 & 2.600 & $2.50 \%$ & 202 & 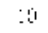 & $\therefore .758$ & 175 & 372 \\
\hline \multirow[t]{2}{*}{20} & 2.130 & 2434 & 212 & 70 & $: 729$ & 1.727 & 137 \\
\hline & " & 2.129 & 112 & 10 & 1.678 & 167 & 140 \\
\hline
\end{tabular}

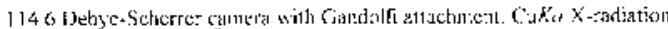

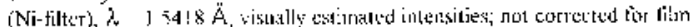

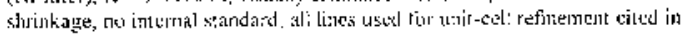
the $[2 \mathrm{xt} ; \mathrm{t} 3=$ |xrngd lims:
Gd and $\mathrm{Tb}(\leq 14.88,7.59$ and $3.31 \mathrm{wt} . \%$ oxides, respectively; Masau et al. 2000b), and a mineral with composition of $\mathrm{Y}(\mathrm{Ta}, \mathrm{Nb}) \mathrm{O}_{4}$ [probable formanite-( $\left.\mathrm{Y}\right)$ ] contains, in wt.\%, $9.05 \mathrm{Gd}_{2} \mathrm{O}_{3}, 7.18 \mathrm{Dy}_{2} \mathrm{O}_{3}$ and $3.22 \mathrm{Sm}_{2} \mathrm{O}_{3}$ (unpublished data of the authors). These two minerals also defy the crystal-chemical preferences of their structures, and they occur isolated from any potentially competing phases.

The enrichment of all three minerals in $M R E E$ strongly suggests that this signature was a general feature of the parent pegmatite-forming melt from which the Annie Claim \#3 pod solidified. The magma, residual after crystallization of a sizeable body of $R E E$-poor leucogranitic parent, was significantly enriched in $\mathrm{H}_{2} \mathrm{O}$, $\mathrm{F}$, Li (and probably also $\mathrm{CO}_{2}$, the abundance of which is documented in late fluid inclusions). Such a volatilerich environment of a highly hydrous melt could have been conducive not only to probable promotion of the tetrad effect (Masau et al. 2000b; see also Fig. 3), but to complexing of the REE as early as during the solidification of the parent granite. Complexing, selective in terms
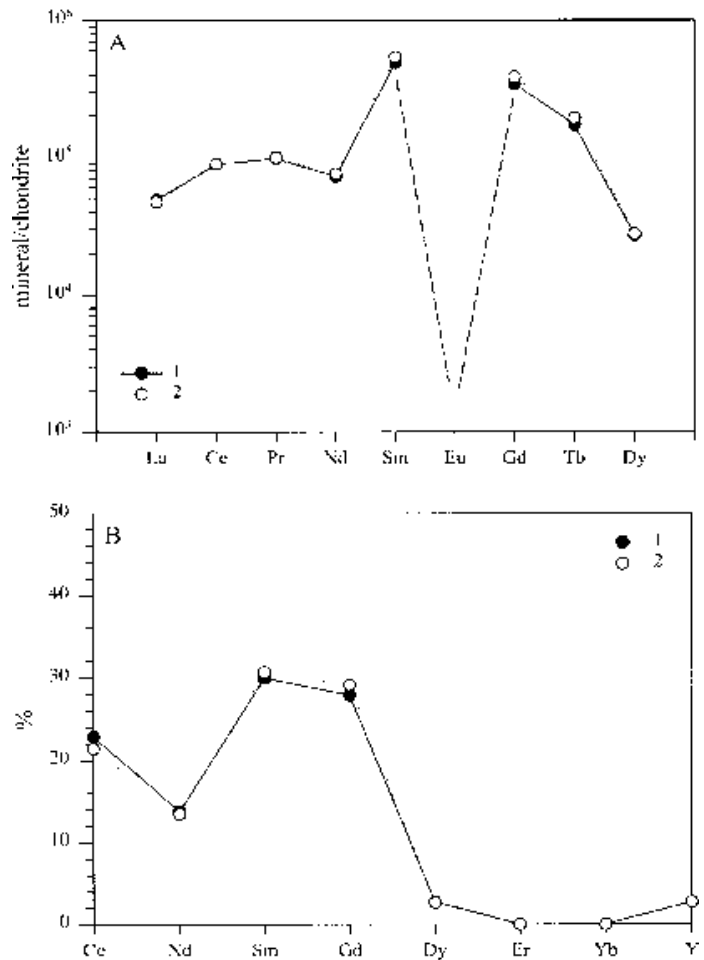

FIG. 3. REE abundances in three grains of monazite-( $\mathrm{Sm})$ : (A) chondrite-normalized pattern using values of Taylor \& McLennan (1985); (B) concentrations of even-numbered $R E E$ and Y (wt.\%) normalized to a total of 100 (as used by Vlasov 1966). Note the prominence of Sm and Gd in both diagrams, and the high value of chondrite-normalized $\mathrm{Tb}$. 
of individual REE and differential in terms of complex stabilities, proposed by Gramaccioli \& Pezzotta (2000; see also Pezzotta et al. 1999, Gramaccioli et al. 1999) could have generated the MREE-enriched signature of the residual pegmatite. Despite the recent progress in studies devoted to REE complexing at relatively low temperatures (e.g., Wood 1990, 1996), experiments under magmatic conditions bordering to supercritical are desirable to address problems such as that posed by our $M R E E$-dominant minerals. Moreover, granitic pegmatites are notorious for disequilibrium crystallization, the $R E E$ minerals are rare and isolated from each other in the pegmatite examined, and the analytical data are incomplete for the REE. Consequently, any further discussion of the possible role of the tetrad effect versus the F-controlled enhancement or dispersal of different $R E E$ in fluid and solid phases (C.M. Gramaccioli, pers. commun., 2001) seems to be futile at present.

Minerals of the monazite and xenotime groups are very scarce in, and rarely recovered in any quantities from, highly fractionated granitic pegmatites rich in $\mathrm{Li}$, $\mathrm{Rb}, \mathrm{Cs}, \mathrm{F}, \mathrm{B}$ and $\mathrm{P}$ (mainly the lepidolite, spodumene and petalite subtypes of rare-element pegmatites of Černý 1991). Any finds of these phases from such environments should be thoroughly examined, as their $R E E$ patterns may help to shed light on fractionation of these elements in highly evolved, complex and ligand-rich environments. REE abundances in accessory minerals, which currently seem to represent only a few exotic anomalies, may prove to be typical of specific categories of pegmatite and the conditions of their derivation and consolidation.

\section{ACKNOWLEDGEMENTS}

This work is one of several extensions of the B.Sc. (Honours) thesis of MM (Masau 1999), supported by NSERC Research, Major Installation and Equipment Grants to PČ and F.C. Hawthorne. G.S. Clark's assistance in isotopic calculations, the reviews by $\mathrm{F}$. Demartin, S. Graeser and C.M. Gramaccioli, and the editorial improvements by R.F. Martin are gratefully acknowledged.

\section{REFERENCES}

ÅMLI, R \& GRIFFIN, W.L. (1975): Microprobe analysis of REE minerals using empirical correction factors. Am. Mineral. 60, 599-606.

Anthony, J.W., Bideaux, R.A., Bladh, K.W. \& Nichols, M.C. (2000): Handbook of Mineralogy. IV. Arsenates, Phosphates, Vanadates. Mineral Data Publishing, Tucson, Arizona.

BaAdsgaARd, H. \& ČernÝ, P. (1993): Geochronological studies in the Winnipeg River pegmatite populations, southeastern Manitoba. Geol. Assoc. Can. - Mineral. Assoc. Can., Program Abstr. 18, A-5.
Burnotte, E., Pirard, E. \& Michel, G. (1989): Genesis of gray monazites: evidence from the Paleozoic of Belgium. Econ. Geol. 84, 1417-1429.

ČERnÝ, P. (1991): Rare-element granitic pegmatites. I. Anatomy and internal evolution of pegmatite deposits. Geosci. Canada 18, 49-67.

Trueman, D.L., ZiehlKe, D.V., Goad, B.E. \& Paul, B.J. (1981): The Cat Lake - Winnipeg River and Wekusko Lake pegmatite fields, Manitoba. Manitoba Dep. Energy and Mines, Mineral. Res. Div., Econ. Geol. Rep. ER80-1.

Demartin, F., Pilati, T., Diella, V., Donzelli, S. \& GramaCcioli, C.M. (1991): Alpine monazite: further data. Can. Mineral. 29, 61-67.

Donnot, M., Guigues, J., Lulzac, Y., Magnien, A., PARfenoff, A. \& Picot, P. (1973): Un nouveau type de gisement d'europium: la monazite grise à europium en nodules dans les schistes paléozoïques de Bretagne. Mineral. Deposita 8, 7-18.

FleisCHER, M. \& AltSCHULER, Z.S. (1969): The relationship of the rare-earth composition of minerals to geological environment. Geochim. Cosmochim. Acta 33, 725-732.

FÖRSTER, H.-J. (1998): The chemical composition of REE-Y$\mathrm{Th}-\mathrm{U}$-rich accessory minerals in peraluminous granites of the Erzgebirge-Fichtelgebirge region, Germany. II. Xenotime. Am. Mineral. 83, 1302-1315.

Harlov, D.E. \& Milke, R. (2000): Composition and $\mathrm{Th}-\mathrm{U}-$ total $\mathrm{Pb}$ ages of huttonite and thorite from Gillespie's Beach, South Island, New Zealand. Can. Mineral. 38, 675-684.

\& RHEDE, D. (1995): Composition of monazite and xenotime from the Fichtelgebirge granites - an electron microprobe study. Ber. Deutsch. Mineral. Gesellsch. 7(1), 68 (abstr.).

Franz, G., Andrehs, G. \& Rhede, D. (1996): Crystal chemistry of monazite and xenotime from SaxothuringianMoldanubian metapelites, NE Bavaria, Germany. Eur. $J$. Mineral. 8, 1097-1118.

Gaines, R.V., Skinner, H.C.W., Foord, E.E., Mason, B. \& Rosenzweig, A. (1997): Dana's New Mineralogy. John Wiley \& Sons New York, N.Y.

Graeser, S. \& Schwander, H. (1987): Gasparite-(Ce) and monazite-(Nd): two new minerals to the monazite group from the Alps. Schweiz. Mineral. Petrogr. Mitt. 67, 103113.

Gramaccioli, C.M., Diella, V. \& Demartin, F. (1999): The role of fluoride complexes in REE geochemistry and the importance of $4 \mathrm{f}$ electrons: some examples in minerals. Eur. J. Mineral. 11, 983-992.

\& Pezzotta, F. (2000): Geochemistry of yttrium with respect to the REE elements in pegmatites. In 
Mineralogy and Petrology of Shallow Depth Pegmatites (F. Pezzotta, ed.). Mem. Soc. Ital. di Scienze Naturali e del Museo di Storia Naturale di Milano 30, 111-115.

LEe, D.E. \& BASTRON, H. (1967): Fractionation of rare-earth elements in allanite and monazite as related to geology of the Mt. Wheeler mine area, Nevada. Geochim. Cosmochim. Acta 31, 339-356.

Masau, M. (1999): Mineralogy and Geochemistry of the Annie Claim No. 3 Pegmatite Pod at Greer Lake, Southeastern Manitoba. B.Sc. thesis, Univ. of Manitoba, Winnipeg, Manitoba.

ČERNÝ, P. \& CHAPMAN, R. (2000a): Exsolution of zirconian-hafnian wodginite from manganoan-tantalian cassiterite, Annie Claim \#3 granitic pegmatite, southeastern Manitoba, Canada. Can. Mineral. 38, 685-694. $\&$ (2000b):Dysprosian xenotime-(Y) from the Annie Claim \#3 granitic pegmatite, southeastern Manitoba, Canada: evidence of the tetrad effect? Can. Mineral. 38, 899-905.

NAGY, G. (1993): "Quick" method for REE mineral analysis by EMPA. In Symp. Rare Earth Minerals: Chemistry, Origin and Ore Deposits (London). Mineral. Soc. and Nat. Hist. Museum, Abstr., 94-96.

Neumann, H., Jensen, B.B. \& Brunfelt, A.O. (1966): Distribution patterns of rare earth elements in minerals. Norsk Geol. Tidssk. 46, 141-179.

Ni, Yunxiang, Hughes, J.M. \& Mariano, A.N. (1995): Crystal chemistry of the monazite and xenotime structures. Am. Mineral. 80, 21-26.

Petruk, W. \& Owens, De'A. (1975): Monazite from the Mount Pleasant deposit, New Brunswick. Can. Mineral. 13, 298-299.

Pezzotta, F., Diella, V. \& Guastoni, A. (1999): Chemical and paragenetic data on gadolinite-group minerals from Baveno and Cuasso al Monte, southern Alps, Italy. Am. Mineral. 84, 782-789.

Pouchou, J.-L. \& Pichoir, F. (1984): A new model for quantitative analysis. 1. Application to the analysis of homogeneous samples. Recherche Aérosp. 5, 47-65.
$\&$

(1985): "PAP" $(\phi \rho Z)$ procedure for improved quantitative microanalysis. In Microbeam Analysis (J.T. Armstrong, ed.). San Francisco Press, San Francisco, California (104-106).

TAYLOR, S.R. \& MCLEnNAN, S.M. (1985): The Continental Crust: Its Composition and Evolution. Blackwell Sci. Publ., London, U.K.

Vainshtein, E.E., Tugarinov, A.I. \& Turanskaya, N.V. (1956): Regularities in the distribution of rare earths in certain minerals. Geochemistry, 159-178.

VAn EMden, B., ThoRnBer, M.R. \& Graham, J. \& Lincoln, F.J. (1997): The incorporation of actinides in monazite and xenotime from placer deposits in western Australia. Can. Mineral. 35, 95-104.

Vlasov, K.A., ed. (1966): Geochemistry and Mineralogy of Rare Elements and Genetic Types of Their Deposits. I. Geochemistry of Rare Elements. Israel Progr. Sci. Transl., Jerusalem, Israel.

WARK, D.A. \& Miller, C.F. (1993): Accessory mineral behavior during differentiation of a granite suite: monazite, xenotime and zircon in the Sweetwater wash pluton, southeastern California. Chem. Geol. 110, 49-67.

WAtT, G.R (1995): High-thorium monazite-(Ce) formed during disequilibrium melting of metapelites under granulite-facies conditions. Mineral. Mag. 59, 735-743.

Wood, S.A. (1990): The aqueous geochemistry of rare-earth elements and yttrium. 2. Theoretical predictions of speciation in hydrothermal solutions to $350^{\circ} \mathrm{C}$ at saturation water vapor pressure. Chem. Geol. 82, 99-125.

(1996): Determination of stability constants for REE complexes at elevated temperature; acetate and chloride complexes of $\mathrm{Nd}$ to $300^{\circ} \mathrm{C}$. Int. Geol. Congress (Beijing), Abstr. 30(3), 34 (abstr.).

Received July 23, 2001, revised manuscript accepted September 28, 2002. 